\begin{tabular}{|l|l|l|l|l|}
\hline Jurnal Penelitian \& PKM & Juli 2017 & Vol 4, No: 2 & Hal: $129-389$ & ISSN \\
\hline
\end{tabular}

\title{
FAKTOR PENYEBAB TERGABUNGNYA REMAJA KOTA BANDUNG DALAM KOMUNITAS KENAKALAN REMEJA
}

\author{
OLEH: \\ YUSTIKA TRI DEWI ${ }^{1}$, BUDHI WIBAWA², ARIE SURYA GAUTAMA ${ }^{3}$
}

\begin{abstract}
1. Mahasiswa Program Studi Sarjana (S-1) Kesejahteraan Sosial Fakultas Ilmu Sosial dan Ilmu Politik Universitas Padjadjaran 2. Pusat Studi Kewirausahaan Sosial, CSR dan Pengembangan Masyarakat Fakultas Ilmu Sosial dan Ilmu Politik Universitas Padjadjaran 3. Departemen Kesejahteraan Sosial Fakultas Ilmu Sosial dan IImu Politik Universitas Padjadjaran

Email:

(yustikatdj@gmail.com¹,budhiwhibawa@gmail.com²,ariesurya.gautama@gmail.com³)
\end{abstract}

\begin{abstract}
ABSTRAK
Kenakalan remaja merupakan hal yang tidak jarang kita temui saat ini. Kenakalan remaja pun tak urung timbul dari sebuah komunitas remaja. Tawuran antar pelajar dari komunitas-komunitas di sekolah, ugalugalan di jalan raya, berpesta minuman keras adalah sebagian contoh dari tindakan kenakalan remaja dalam komunitas. Kenakalan remaja tersebut dapat terjadi dari pengaruh suatu komunitas. Remaja di Kota Bandung sudah sangat akrab dengan budaya yang mengharuskan seorang remaja masuk ke dalam komunitas. Akibatnya, Kota Bandung terkenal dengan komunitas antar sekolah untuk para remaja, komunitas geng motor dan komunitas lainnya. Sayangnya banyak pandangan negatif karena biasanya komunitas remaja sering melakukan tindak kenakalan dan tak jarang meresahkan lingkungan serta masyarakat sekitar. Padahal sudah cukup diakui secara global adanya tindak kenakalan remaja disebabkan faktor-faktor tertentu. Jika sudah banyak penelitian yang mencari faktor penyebab adanya tindak kenakalan remaja, penelitian ini lebih memfokuskan kepada faktor-faktor penyabab masuknya remaja dalam komunitas yang sering melakukan tindak kenakalan remaja. Dengan cara observasi langsung dan wawancara mendalam dengan anggota komunitas yang terkenal sering melakukan tindak kenakalan, diharakpakn penelitian ini dapat menyimpulkan fakor penyebab yang mendukung remaja bergabung. Faktor penyebab remaja bergabung dalam sebuah komunitas kenakalan remaja, diyakini mempunyai dua faktor penentu yaitu faktor pendorong dan faktor penarik.
\end{abstract}

Kata kunci: remaja, kenakalan remaja, komunitas, faktor-faktor penyebab 


\begin{tabular}{|c|c|c|c|c|}
\hline Jurnal Penelitian \& PKM & Juli 2017 & Vol 4, No: 2 & Hal: $129-389$ & $\begin{array}{c}\text { ISSN } \\
2442-448 X(p), 2581-1126(e)\end{array}$ \\
\hline
\end{tabular}

\section{ABSTRAC}

Juvenile delinquency is something we are not uncommon today. Juvenile delinquency did not fail to arise from a teen community. Student strikes from school communities, inconsiderate on the highway, hard partying are some examples of juvenile delinquency in the community. Juvenile delinquency can occur from the influence of a community. Teenagers in the city of Bandung is very familiar with the culture that requires a teenager into the community. As a result, Bandung is famous for inter-school communities for teenagers, motorcycle gangs and other communities. Unfortunately many negative views because usually teenagers often commit misbehavior and often spoil the environment and the surrounding community. Though it has been sufficiently recognized globally the act of juvenile delinquency caused by certain factors. If there are many studies that look for factors causing juvenile delinquency, this research focuses more on the factors of penyabab entry of adolescents in the community who often do juvenile delinquency. By way of direct observation and in-depth interviews with well-known members of the community often misbehavior, this study may infer the fakor causes that support juveniles join. Factors that cause adolescents to join in a juvenile delinquency community, is believed to have two determinants of factors driving and pull factors.

Keywords: teenager, juvenile delinquency, community, causes factors

\section{PENDAHULUAN}

Masa remaja merupakan peralihan dari masa kanak-kanak ke dewasa awal atau dikenal dengan masa transisi. Masa transisi dirasakan sebagai suatu masa krisis karena jiwa mereka yang sedang mengalami pembentukan keadaan emosi dan perasaan (Rumini, 1997). Remaja mempunyai semangat yang tinggi dalam meraih suatu tujuan. Remaja akan mencoba segala hal baru yang menarik perhatian mereka. Remaja juga belajar untuk memecahkan dan keluar dari masalah yang mereka hadapi (Curtis, 2015). Pada periode tersebut remaja merasa harus mempunyai reputasi akan dirinya sendiri. Hal tersebut yang mendorong remaja cenderung mencari pengakuan identitas diri dengan cara bergabung di dalam suatu kelompok atau komunitas tertentu.
Remaja memang mempunyai naluri dalam membentuk maupun bergabung ke dalam suatu kelompok teman sebaya atau komunitas tertentu. Remaja merasa harus mempunyai teman yang mempunyai tujuan dan kepentingan yang sama. Selain itu, remaja cenderung mencari komunitas yang akan menggambarkan dirinya. Hal tersebut yang kerap dijadikan alasan tentang remaja beresiko (Carroll, Houghton, Durkin, \& Hattie, 2009). Masuknya seorang remaja ke dalam suatu komunitas bukanlah hal yang berdampak negatif atau beresiko. Tetapi, terdapat beberapa komunitas remaja yang sering membuat masalah yang termasuk ke dalam juvenile delinquency.

Juvenile delinquency atau kenakalan remaja adalah hal yang perlu mendapat perhatian lebih dewasa ini. Kenakalan remaja (juvenile delinquency) adalah suatu perbuatan yang 
melanggar norma, aturan atau hukum dalam masyarakat yang dilakukan pada usia remaja. Kenakalan remaja juga dikenal sebagai penyimpangan perilaku yaitu dengan berpartisipasinya seorang remaja dalam perilaku ilegal (Siegel \& Welsh, 2013). Dilansir oleh Kompas.com tentang crime index atau indeks kejahatan di Indonesia selama 2016, ada 11 jenis kasus yang meningkat salah satunya kenakalan remaja dengan presentase $400 \%$ atau sama dengan bertambahnya 5 kasus (Kompas.com, 2016). Kenakalan remaja yang sering ditemukan adalah bolos sekolah, tawuran, perkelahian, penyalahgunaan narkoba, mengonsumsi alkohol, pelecehan seksual, pencurian, sampai kepada tindak kriminal yang dapat merenggut nyawa orang lain (Kim \& Kim, 2008).

Kenakalan remaja dapat terjadi dari pengaruh suatu komunitas. Adanya ikatan antar anggota yang berupa partisipasi dalam setiap kegiatan komunitas, dapat berdampak buruk jika kegiatan tersebut termasuk ke dalam perilaku menyimpang. Adanya rasa menghormati budaya, tradisi dan kebiasaan di dalam komunitas membuat anggota seakan tidak perduli akan dampak yang mereka buat. Meskipun tidak semua kegiatan di dalam suatu komunitas terukur buruk, tetapi terdapatnya kenakalan remaja yang berasal dari suatu komunitas juga tidak jarang ditemui di beberapa tahun silam.

Di tahun 2014, puluhan alumni SMA Negeri 5 Bandung dan SMA Negeri 20 Bandung terlibat tawuran tepat di Jl. Belitung, Kota Bandung. Kabag Ops Polrestabes Bandung, AKBP Diki Budiman, mengatakan perselisihan terjadi saat alumni SMAN 20 Bandung angkatan 2012, 2013 dan 2014 melakukan konvoi usai kegiatan buka bersama di sekolah. Konvoi tersebut melewati Taman Musik Centrum, disaat terdapat alumni dan pelajar SMA Negeri 5 Bandung yang sedang nongkrong. Dikemukakan, beberapa alumni SMA Negeri 20 Bandung terlibat cekcok dengan alumni SMA Negeri 5 Bandung dan berakhir dengan aksi lempar batu. Ternyata kedua kelompok dari sekolah yang berbeda tersebut memang dikenal mempunyai konflik dari jaman dahulu (CB Magazine, 2014).

Dari paparan berita tersebut, peneliti menganggap kegiatan tawuran berasal dari rasa kecintaan dan saling melindungi dalam kelompok atau komunitas. Para alumni pun masih melakukan tawuran atas dasar kesetiaan dan kekompakan pada kelompok atau komunitasnya. Begitu juga dengan keyakinan para anggota kelompok dan komunitas tentang kebiasan dan budaya yang dilakukan oleh para anggota lamanya. Hal tersebut sering dijadikan alasan untuk berprilaku menyimpang. Walupun sebenarnya banyak remaja yang menyadari bahwa perilaku tersebut merupakan tindak kenakalan remaja.

Kenakalan remaja juga termasuk ke dalam hal yang menentang peraturan undang-undang seperti penyalahgunaan narkoba dan meminum minuman beralkohol. Kegiatan tersebut biasa dilakukan para remaja bersama kelompok atau komunitasnya. Pada tahun 2015, Pikiran Rakyat memberitakan sebanyak sepuluh ribu anak di Indonesia saat ini berhadapan dengan hukum. Banyak dari mereka tersangkut kasus narkoba, kesusilaan dan perkelahian (Supriadi, 2015). Badan Narkotika Nasional Provinsi (BNNP) Jawa Barat mencatat pada tahun 2013, kalangan pelajar tingkat SMP dan SMA adalah pengguna narkoba 
paling tinggi di Jawa Barat. Wilayah Jawa Barat yang tertinggi pada penyalahgunaan narkoba ialah Kota Bandung. Mayoritas berjenis kelamin pria dan sering ditemukan menggunakan narkoba bersama para anggota komunitasnya (detikNews, 2013).

Peneliti telah melakukan kajian terhadap penelitian terdahulu terkait juvenile delinquency (kenakalan remaja). Penelitian dilakukan oleh K. M. Banham Bridges dalam sebuah jurnal yang berjudul "Factors Contirbuting to Juvenile Delinquency". Penelitian tersebut membahas tentang faktor-faktor yang berkontribusi dalam terwujudnya kenakalan pada remaja. Faktor-faktor tersebut anatara lain; faktor kesehatan fisik dan mental, kondisi keluarga, kondisi lingkungan sekolah yang termasuk dalam kelompok teman sebaya dan komunitas. Dimana dijelaskan bahwa terjadinya kenakalan remaja dalam suatu komunitas, dipengaruhi faktor keberanian bersama untuk menanggung resiko (Bridges, 2013).

Penelitian yang telah dipaparkan sebelumnya memberi gambaran tentang faktorfaktor yang mendorong remaja melakukan tindakan kenakalan, antara lain komunitas yang memberi pengaruh terhadap perilaku remaja. Penelitian ini memfokuskan kajian kepada faktorfaktor apa yang menyebabkan para remaja bergabung dalam komunitas yang sering melakukan juvenile delinquency (kenakalan remaja). Didalam buku Juvenile Delinquency: $A n$ Intergrated Approach dijelaskan bahwa adanya perilaku kenakalan remaja merupakan hubungan yang didahului oleh masalah internal dan dilanjutkan dengan bergabungnya ke dalam suatu komunitas, yang akhirnya menciptakan perilaku kenakalan (Burfeind \& Bartusch, 2006).
Hubungan penyebab kenakalan remaja juga diperkuat oleh Donald J. Shoemaker di buku berjudul Juvenile Delinquency (2 ${ }^{\text {nd }}$ Edition). Masalah yang terjadi di lingkungan keluarga seperti broken home sangat berpotensi membuat remaja menjadi pelaku kenakalan. Hal tersebut disebabkan sudah tidak adanya lagi ikatan yang kuat antar anggota keluarga, sehingga remaja cenderung mencari sosok pengganti keluarga yaitu dengan mencari kelompok teman sebaya dan bergabung ke dalam suatu komunitas. Shoemaker melanjutkan, teman sebaya atau komunitas adalah sumber motivasi terbesar yang mempengaruhi perilaku kenakalan remaja (Shoemaker, 2013). Faktor masalah keluarga yang dijelaskan oleh Shoemaker, merupakan gambaran dari masalah internal yang dikemukakan Burfeind \& Bartusch dalam ilustrasi hubungan penyebab kenakalan remaja.

Family role factor dan school controlling factor juga disebut sebagai faktor penyebab seorang remaja bergabung dalam komunitas berprilaku nakal. Hal tersebut dikemukakan oleh Adrianus Suryanto di dalam artikelnya yang berjudul Juvenile Delinquency in Indonesia (Suryanto). Peran keluarga dirasa tidak lagi berfungsi untuk memperhatikan dan membimbing disebabkan masalah seperti perceraian orang tua maupun krisis ekonomi keluarga. Begitu pula dengan kontrol dari sekolah untuk siswanya yang cenderung tidak setuju dengan aturan-aturan yang dibuat sekolah maupun pemerintah, sehingga membuat perlawanan dengan cara bergabung ke dalam suatu komunitas yang sering melakukan tindak kenakalan. 


\begin{tabular}{|l|l|l|l|l|}
\hline Jurnal Penelitian \& PKM & Juli 2017 & Vol 4, No: 2 & Hal: $129-389$ & ISSN \\
\hline
\end{tabular}

Kenakalan remaja dianggap peneliti sebagai hal yang urgensi karena tidak hanya menyangkut masalah individu melainkan masalah sosial. Selain merugikan individu remaja tersebut, kenakalan remaja sangat merugikan masyarakat dan negara. Remaja merupakan generasi peneurs bangsa yang sangat diharapkan dapat menjadi individu yang cakap dalam pengetahuan maupun keterampilan. Kenakalan remaja jaga merupakan hal yang merisihkan masyarakat, sehingga peneliti meyakini kenakalan remaja adalah hal urgensi yang harus diselesaikan.

Peneliti beranggapan bahwa kenakalan remaja dapat dicegah jika remaja tidak memilih untuk mengikuti suatu komunitas yang dikenal sering melakukan tindakan juvenile delinquency (kenakalan remaja). Seperti yang telah diuraikan sebelumnya, jika kita mengetahui faktor-faktor apa yang menyebabkan para remaja bergabung dalam komunitas yang sering melakukan juvenile delinquency (kenakalan remaja), upaya prenventif dapat diterapkan khususnya dari bidang pekerja sosial dengan memfokuskan faktor-faktor penyebab tersebut.

\section{METODE, HASIL DAN PEMBAHASAN}

\section{Pendekatan Penelitian}

Metode yang digunakan dalam penelitian ini adalah studi literatur. Studi literatur adalah mencari relefensi teori yang relefan dengan kasus atau permasalahan yang ditemukan. Referensi dapat dicari dari buku, jurnal, artikel laporan penelitian, dan situs internet yang mumpuni. Output dari studi literatur adalah terkoleksinya referensi yang relevan dengan perumusan masalah.

\section{Hasil dan Pembahasan}

Kenakalan Remaja

Juvenile Delinquency adalah istilah asing yang berarti kenakalan remaja. Kenakalan remaja (juvenile delinquency) adalah suatu perbuatan yang melanggar norma, aturan atau hukum dalam masyarakat yang dilakukan pada usia remaja. Kenakalan remaja juga dikenal sebagai penyimpangan perilaku yaitu dengan berpartisipasinya seorang remaja dalam perilaku ilegal (Siegel \& Welsh, 2013).

(Sumiati, 2009), mendefinisikan kenakalan remaja adalah suatu perilaku yang dilakukan oleh remaja dengan mengabaikan nilai-nilai sosial yang berlaku di dalam masyarakat. Kenakalan remaja meliputi semua perilaku yang menyimpang dari norma-norma dan hukum yang dilakukan oleh remaja. Perilaku ini dapat merugikan dirinya sendiri dan orang-orang sekitarnya.

Kartono, seorang ilmuwan sosiologi membuat definisi kenakalan remaja di dalam bukunya yang berjudul "Patologi Sosial 2: Kenakalan Remaja" (Kartono, 2014), yaitu bahwa:

" Kenakalan Remaja atau dalam Bahasa Inggris dikenal dengan istilah juvenile delinquency merupakan gejala patologis social pada remaja yang disebabkan oleh satu bentuk pengabaian social. Akibatnya, mereka mengembangkan bentuk perilaku yang menyimpang."

Berdasarkan beberapa definisi para ahli diatas, peneliti menyimpulkan kenakalan remaja 
merupakan tingkah laku yang melampaui batas toleransi orang lain atau lingkungan sekitar, serta suatu tindakan yang dapat melanggar normanorma dan hokum. Secara sosial kenakalan remaja ini dapat disebabkan oleh bentuk pengabaian sosial sehingga remaja dapat mengembangkan bentuk perilaku yang menyimpang.

\section{Konsep Komunitas}

Kelompok sosial adalah sebuah naluri manusia sejak ia dilahirkan. Naluri ini yang selalu mendorongnya untuk selalu menyatukan hidupnya dengan orang lain dalam kelompoknya. Naluri berkelompok itu juga yang mendorong manusia untuk menyatukan dirinya dengan kelompok yang lebih besar dalam kehidupan manusia lain disekelilingnya bahkan mendorong manusia menyatu dengan alam fisiknya. Untuk memenuhi naluriah manusia ini, maka setiap manusia setiap melakukan proses keterlibatannya dengan orang lain dan lingkungannya, proses ini dinamakan adaptasi. Adaptasi dengan kedua lingkungan tadi; manusia lain dan alam sekitarnya itu, melahirkan struktur sosial baru yang disebut dengan kelompok sosial. Kelompok sosial adalah kehidupan bersama manusia dalam himpunan atau kesatuan kesatuan manusia yang umumnya secara fisik relatif kecil yang hidup secara guyub (Bungin, 2009, p. 48).

Menurut Soerjono Soekanto, istilah community dapat diterjemahkan sebagai "masyarakat setempat". Istilah yang menunjuk pada warga sebuah desa, sebuah kota, suku, atau suatu bangsa. Apabila anggota sesuatu kelompok baik kelompok besar maupun kelompok kecil hidup bersama sedemikian rupa sehingga mereka merasakan bahwa kelompok tersebut memenuhi kepentingan hidup yang utama, kelompok tersebut disebut dengan masyarakat setempat (Santosa, 2004, p. 83).

Community berasal dari bahasa Latin yang artinya komunitas. Komunitas adalah sebuah kelompok sosial dari beberapa organisme yang berbagi lingkungan, umumnya memiliki ketertarikan dan habitat yang sama. Dalam komunitas manusia, individu - individu di dalamnya dapat memliki maksud, kepercayaan, sumberdaya, preferensi, kebutuhan, resiko dan sejumlah kondisi lain yang serupa.

Ada beberapa faktor yang melatar belakangi timbulnya community, antara lain sebagai berikut: (Santosa, 2004)

1. Adanya suatu interaksi yang lebih besar diantara anggota yang bertempat tinggal disatu daerah dnegan batas - batas tertentu.

2. Adanya norma sosial manusia didalam masyarakat, diantaranya kebudayaan masyarakat sebagai suatu ketergantungan yang normatif, norma kemasyarakatan yang historis, perbedaan sosial budaya antara lembaga kemasyarakatan dan organisasi masyarakat.

3. Adanya keter3gantungan antara kebudayaan dan masyarakat yang bersifat normatif. Demikian juga norma yang ada dalam masyarakat akan memberikan batas - batas kelakuan pada anggotanya dan dapat berfungsi sebagai pedoman bagi kelompok untuk menyumbangkan sikap dan kebersamaannya dimana mereka berada. 


\begin{tabular}{|l|l|l|l|l|}
\hline Jurnal Penelitian \& PKM & Juli 2017 & Vol 4, No: 2 & Hal: $129-389$ & ISSN $2442-448 X(\mathrm{p}), 2581-1126(\mathrm{e})$ \\
\hline
\end{tabular}

Salah satu fungsi penting yang dijalankan community, yaitu fungsi mengadakan pasar karena aktifitas ekonomi. Selain sebagai pusat pertukaran jasa-jasa di bidang politik, agama, pendidikan, rekreasi, dan sebagainya. Disamping itu di dalam komunitas ditandai dengan adanya hubungan sosial antara anggota kelompok masyarakat.

Remaja kota Bandung hingga kini masih berpegang teguh dengan budaya mengikuti komunitas baik di lingkungan sekolah maupun tempat tinggal. Tak sedikit, komunitas tempat mereka bergabung adalah komunitas yang sering melakukan tindak kenalan remaja. Kenakalan remaja atau juvenile delinquency sangat dikenal di rancah global dan termasuk kepada hal yang perlu mendapat perhatian lebih saat ini. Peneliti beranggapan, masuknya seorang remaja ke dalam komunitas tidak hanya didasari oleh sekedar budaya yang turun menurun tetapi juga banyak faktor-faktor lain yang mempengaruhi.

Faktor-faktor penyebab remaja bergabung ke dalam suatu komunitas yang sering melakukan kenakalan remaja, dibagi menjadi dua faktor penentu. Faktor pertama adalah faktor pendorong atau push factors dan faktor penarik atau pull factors. Faktor pendorong adalah faktor yang mendorong remaja ingin bergabung dalam suatu komunitas, contohnya faktor internal yaitu masalah keluarga. Sedangkan faktor penarik adalah faktor yang menarik remaja untuk masuk ke dalam suatu komunitas tertentu, contohnya adanya pengakuan dari dalam komunitas tentang eksistensi seorang remaja.

\section{SIMPULAN DAN SARAN}

Merujuk pada studi literatur yang dilakukan oleh peneliti, maka penelitian mengenai faktor penyebab tergabungnya remaja di dalam komunitas kenakalan remaja dapat memperoleh informasi dan teori terkait mengenai faktor-faktor penarik maupun faktor-faktor penyebab. Selain itu, teori terkati faktor penyebab diharpakan dapat membuka mata masyarakat awam dalam melihat fenomena kenakalan remaja terutama yang disebabkan oleh sekelompok komunitas.

\section{DAFTAR PUSTAKA}

\section{Buku}

Rumini, S. (1997). Psikologi Pendidikan. Yogyakarta: UPP IKIP Yogyakarta.

Curtis, A. C. (2015). Defining Adolescence. Journal of Adolescence and Family Heatlh, $72)$.

Carroll, A., Houghton, S., Durkin, K., \& Hattie, J.
A. (2009). Adolescent Reputations and
Risk. New York: Springer.

Raharjo, ST. 2015. Assessment untuk Praktik Pekerjaan Sosial dan Kesejahteraan Sosial. Bandung: Unpad Press 2015. Dasar Pengetahuan Pekerjaan Sosial. Bandung: Unpad Press. 2015. Keterampilan Pekerjaan Sosial: Dasar-dasar. Bandung, Unpad Press.

Siegel, L. J., \& Welsh, B. C. (2013). Juvenile Delinquency: The Core (4th ed.). New York: Cengage Learning. 


\begin{tabular}{|c|c|c|c|c|}
\hline Jurnal Penelitian \& PKM & Juli 2017 & Vol 4, No: 2 & Hal: $129-389$ & $\begin{array}{c}\text { ISSN } \\
\text { 2442-448X (p), 2581-1126 (e) }\end{array}$ \\
\hline
\end{tabular}

Kim, H.-S., \& Kim, H.-S. (2008). Juvenile

Delinquency and Youth Crime. New York: Nova Science Publisher.

Shoemaker, D. J. (2013). JUVENILE DELINQUENCY. The Journal of Academic Social Science Studies, 578-588.

\section{Bab dalam Buku}

Burfeind, J., \& Bartusch, D. J. (2006). The Study of Juvenile Delinquency. In J. Burfeind, \& D. J. Bartusch, Juvenile Delinquency: An Integrated Approach (2nd ed., pp. 10-11). London: Jones and Bartlett Publisher International.

\section{Hasil Penelitian}

Bridges, K. M. (2013). Factors Contributing to Juvenile Delinquency. Journal of Criminal Law and Criminology.

\section{Rujukan Elektronik}

Kompas.com. (2016, Desember 29). Ini 11 Jenis Kejahatan yang Menonjol Selama 2016. Retrieved Maret 24, 2017, from megapolitan.kompas.com: http://megapolitan.kompas.com/read/201 6/12/29/17470511/ini.11.jenis.kejahatan. yang.menonjol.selama.2016

CB Magazine. (2014, July 21). Alumni SMAN 5 dan SMAN 20 Bandung Tawuran. Retrieved Maret 24, 2017, from cbmagazine.blogspot.co.id: http://cb- magazine.blogspot.co.id/2014/07/alumnisman-5-dan-sman-20-bandung.html

Supriadi, Y. (2015, Agustus 14). Sepuluh Ribu Anak Kini Berhadapan Dengan Hukum. Retrieved Maret 24, 2017, from www.pikiran-rakyat.com: http://www.pikiran-rakyat.com/bandungraya/2015/08/04/337054/sepuluh-ribuanak-kini-berhadapan-dengan-hukum detikNews. (2013, Februari 19). Duh, Pelajar di Jabar Tertinggi Pengguna Narkoba. Retrieved Maret 24, 2017, from news.detik.com: http://news.detik.com/jawabarat/2173861 /duh-pelajar-di-jabar-tertinggi-penggunanarkoba

\section{Suryanto, A. (n.d.). Juvenile Delinquency in} Indonesia. Retrieved April 7, 2017, from drianyanto.wordpress.com: https://drianyanto.wordpress.com/2011/0 $3 / 21 /$ juvenile-delinquency-in-indonesia/ 